\title{
Encounter between the Prophet's Sunna and the Society Tradition: a Study of Living Sunna in Puncu Sub-District, Kediri District
}

\author{
Wahidul Anam \\ Institut Agama Islam Negeri (IAIN) Kediri, Indonesia \\ wahidulanam@yahoo.co.id
}

\section{Abstract}

Sunna, the prophet Muhammad's traditions and practices, always develop and come to the attention of the next generation of Muslims. Indonesian Muslims as followers of the largest Islamic religion in the world have a unique concept in terms of the struggle of tradition from the relics of local religions with the teachings of Islam. The dialectics proceed dynamically as developed by Walisanga (the nine revered saints of Islam in Indonesia), which was known later as the cultural and religious acculturation model. This paper will describe how the process of religious acculturation with local culture in Puncu Sub-District, Kediri can be implemented well, especially related to their practice in carrying out the traditions of the Prophet Muhammad in their various religious lives. Some fundamental questions to be answered are how the process and form of living Sunna as well as the factors that influence the acculturation process applied in these. For this reason, this type of research is interdisciplinary, by not only based on the science of hadith, but also using an anthropological approach and cultural acculturation theory. The results found include: (1) traditions practiced in Puncu such as rituals in the process of birth, marriage, and body management are forms of living Sunna that have become customs and become part of the acculturation of local religion and culture that is going well; (2) this can be realized with at least a number of factors, including: the role of religious scholars and 
religious leaders with moderate characters, government officials who care about diversity, the existence of religious institutions that contribute to the cultivation of acculturation so as to minimize conflicts between local religions and cultures, as well smooth the agenda of faith and community traditions simultaneously.

Keywords: Living Sunna, Acculturation, Tradition.

\section{Abstrak}

PERTEMUAN ANTARA SUNNAH NABI DAN TRADISI MASYARAKAT: KAJIAN LIVING SUNNAH DI KECAMATAN PUNCU KABUPATEN KEDIRI. Sunnah, tradisi dan praktik Nabi Muhammad saw., selalu berkembang dan menjadi perhatian generasi Muslim berikutnya. Umat Islam Indonesia sebagai pemeluk agama Islam terbesar di dunia memiliki konsep unik dalam hal pergulatan tradisi dari peninggalan agama lokal dengan ajaran Islam. Dialektika berjalan dinamis seperti yang dikembangkan oleh Walisongo (sembilan wali Islam di Indonesia), yangkemudian dikenal sebagaimodelakulturasi budaya dan agama. Artikel ini akan memaparkan bagaimana proses akulturasi agama dengan budaya lokal di Kecamatan Puncu, Kabupaten Kediri dapat terlaksana dengan baik, terutama terkait praktik mereka dalam menjalankan tradisi Nabi Muhammad saw. dalam berbagai kehidupan keagamaannya. Beberapa pertanyaan mendasar yang harus dijawab adalah bagaimana proses dan bentuk Sunnah hidup serta faktor-faktor yang mempengaruhi proses akulturasi yang diterapkan di dalamnya. Oleh karena itu, jenis penelitian ini bersifat interdisipliner, tidak hanya berdasarkan ilmu hadis, tetapi juga menggunakan pendekatan antropologis dan teori akulturasi budaya. Hasil yang ditemukan antara lain: (1) tradisi yang dianut di Puncu seperti ritual dalam proses kelahiran, perkawinan, dan penataan tubuh merupakan bentuk-bentuk Sunnah hidup yang telah menjadi adat istiadat dan menjadi bagian dari akulturasi agama dan budaya setempat yang berjalan dengan baik; (2) hal tersebut dapat terwujud sekurang-kurangnya dengan sejumlah faktor, antara lain: peran ulama dan pemuka agama yang berkarakter moderat, aparatur pemerintah yang peduli terhadap kebhinekaan, keberadaan lembaga keagamaan yang berkontribusi pada pembinaan akulturasi sehingga meminimalisasi konflik antar agama dan budaya lokal serta memperlancar agenda keimanan dan tradisi masyarakat secara bersamaan.

Kata Kunci: Living Sunnah, Akulturasi, Tradisi. 


\section{A. Introduction}

The Prophet's Sunna is a tradition carried out by Prophet Muhammad and has been practiced by his followers in their daily life. One such practice model is through a contextualization process (practical tradition or silent tradition), that is the actualization of the Prophet Muhammad's Sunna by his companions and subsequent generations. ${ }^{1}$ Various individual and different interpretations emerged from the actualization process, resulting in different religious practices among Muslims. ${ }^{2}$ The companions' differences in interpreting the Prophet's Sunna (living Sunna) generated Kufan Sunna, Medinan Sunna, and so on.

Academically, studies on living Qur'an and hadith studies are part of studies on lived religion, practical religion, popular religion, and lived Islam which aim at exploring how human being and society understand and practice religion. Social scientific methods have led researchers on religious study to shift from manuscript studies to present-day living communities of faith. ${ }^{3}$ Therefore, living Sunna studies focus more on the practical aspects of understanding and practice of religion, such as symbols, myths, rituals, and others that manifest in the daily practice. This study focused on the practice of Sunna in Puncu Sub-District, Kediri District.

Puncu Sub-District is an area located in the slopes of Kelud Mountain, Kediri District. Majority of its territory is plateau, mostly used, and is mild climate. Most residents have low level of education and mostly work as farmers. ${ }^{4}$ Historically, most Puncu community were Hindus before Islam came. ${ }^{5}$ Later on, some Puncu community also embraced Kejawen tradition (Javanese religious tradition) and Catholic Christianity, especially in the plantation area in Sukomoro

${ }^{1}$ Saifuddin Zuhri Qudsy, "Living Hadis: Genealogi, Teori, dan Aplikasi”, Jurnal Living Hadis 1, no. 1 (2016), 178.

${ }^{2}$ M. Alfatih Suryadilaga, "Model-model Living Sunnah", Unpublished Paper.

${ }^{3}$ Muhamad Ali, "Kajian Naskah dan Kajian Living Qur'an dan Living Hadith", Journal of Qur'an and Hadith Studies 4, no. 2 (2015), 147-167.

${ }^{4}$ Interview with the Head of Puncu Sub-District, January 4, 2017 at the Puncu SubDistrict Office.

${ }^{5}$ Interview with Islamic cleric Saeroji, February 10, 2017, at Puncu Mosque. 
village and some others embraced Islam much later. ${ }^{6}$ Puncu community lived harmoniously and there was no religious friction. ${ }^{7}$

The question was how Islam as a relatively new religion can acculturate well with the local Puncu community' culture. The reflective question was necessary due to some conflicts between the local culture and new religion in Indonesia. Acculturation is important for religious adherents to express their beliefs in accordance with their socio-cultural conditions. ${ }^{8}$ Puncu Muslim community, for example can practice their religion, including the prophet's Sunna, without pressure in their life.

This paper is the result of a qualitative descriptive research ${ }^{9}$ aimed to observe and analyse the Puncu community' spoken and written languages and observable behaviours. ${ }^{10}$ The study was expected to contribute by describing the process and forms of living Sunna and the factors that influence Puncu community' acculturation process.

\section{B. Discussion}

\section{Literature Review: Living Sunna}

Etymologically, the term living Sunna is constructed from living and Sunna "traditions sourced from the Prophet Muhammad, including words, habits, practices and silent approvals (taqrir), and himmah. According to Rahman, the Qur'an mentioned that the concept of the prophet's Sunna by declaring that the Prophet Muhammad was a beautiful example (uswa hasana). ${ }^{11}$ For Rahman, the Sunna was a valid and operative concept since the very

${ }^{6}$ Observation in Sukomoro, Puncu Village, February 10, 2017.

${ }^{7}$ Observation in Puncu Village Office, February 10, 2017.

${ }^{8}$ Radjasa Mu'tasim, Perlawanan Santri Pinggiran (Yogyakarta: Insan Madani, 2010), 1.

${ }^{9}$ Naila Hayati, "Pemilihan Metode yang Tepat dalam Penelitian: Metode Kuantitatif dan Metode Kualitatif", Jurnal Tarbiyah al-Awlad 4, no. 1 (2015), 346-347. 1991), 3

${ }^{10}$ Lexy J. Moleong, Metodologi Penelitian Kualitatif (Bandung: Remaja Rosdakarya,

${ }^{11}$ Umma Farida, "Studi Pemikiran Fazlur Rahman Tentang Sunnah dan Hadis", ADDIN 7, no. 2 (2013), 230-231. 
beginning of Islam and applied throughout time. ${ }^{12}$ Rahman used "Living Sunna" term and suggested that it was an on going process because it was guided by ijtihad (Islamic jurist's independent reasoning process of finding an answer to a question) and ijma (Islamic scholars' consensus or agreement on Islamic law). ${ }^{13}$ The companions' ijtihad and the living Sunna were then formalized into hadith which lasted until the $3^{\text {rd }}$ century A.D.

The formalization process of hadith resulted in absolute resolutions. Thus, Rahman suggested that the formalism should be loosen and new steps should be taken. ${ }^{14}$ He suggested to reestablish the interaction between the companions' ijtihad and the prophet's Sunna which brought forth the "Living Sunna". In this way, every generation has the opportunity to revive the Prophet's Sunna in accordance with its respective era, as did the early generations of Muslims. ${ }^{15}$

There were at least three models of how Muslims lived under the prophet's Sunna. First, writing tradition, which is a longstanding tradition in the Islamic world through writing of the prophet's hadith for a particular purpose. For example, a hadith regarding the obligation to seek knowledge: ${ }^{16}$

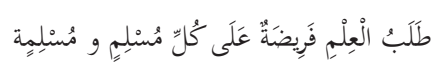

Such texts are often found on boards and building walls, news chapters, and papers, or quoted in sermons.

\footnotetext{
${ }^{12}$ Fazlur Rahman, Revival and Reform in Islam, transl. Aam Fahmia (Jakarta: Raja Grafindo Persada, 2001), 6. See M. Alfatih Suryadilaga, "Model-model Living Hadis".

${ }^{13}$ Taufik Adnan Amal, Islam dan Tantangan Modernitas: Studi atas Pemikiran Hukum Fazlur Rahman (Bandung: Mizan,1996), 168-175.

${ }^{14}$ Amal.

${ }^{15}$ Ghufron A. Mas'adi, Pemikiran Fazlur Rahman Tentang Metodologi Pembaruan Hukum Islam (Jakarta: Raja Grafindo, 1997), 95-96.

${ }^{16}$ The full text of the hadith is:

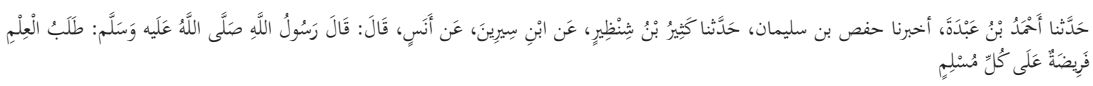

See Abu Bakr al-Bazar, Musnad al-Bazar, Volume 13 (Madinah: Maktabah al-'Ulum wa al-Hikam, 1998), 240. 
Second, oral tradition as a living Sunna. Two examples are weekly salawat recitation by Diba' Bil-Mustofa Salawat Assembly ${ }^{17}$ and the qunut supplication prayer reading inside Maghrib prayers held at Wahid Hasyim Boarding School in Yogyakarta. ${ }^{18}$ Third, tradition of practice, which is a living hadith applied and performed by Muslims according to hadith. For example, bathing on Friday which based on a hadith on bathing prior to Friday prayer. ${ }^{19}$

\section{Relationship with Religious Acculturation}

The study of living Sunna is closely related to a local community's culture especially through acculturation process. Acculturation is a mixing process between conflict and acceptance which makes participating parties possible to face each other in competition, but the each party suppress the tensions in order to create a cohesive atmosphere which fuses their culture into a new reality. ${ }^{20}$

While acculturating, the "acceptor" culture accepts another culture's elements without losing in it. The "acceptor" develops its own structure with foreign material without losing its original identity. ${ }^{21}$ Acculturation occurs as a result of a strong and prestigious culture influences a weak and backward culture, or between two relatively similar cultures. ${ }^{22}$ Thus, acculturation is a blend of two cultures (the immigrant and the local cultures) which operates harmoniously without coercion and struggles between its agents for long period of time.

Some factors to consider in the acculturation process include: (a) the number of people involved; (b) secondary cultural skills; (c) the place where the two cultures comes into contact; (d) contact

${ }^{17}$ Adrika Fithrotul Aini, "Living Hadis dalam Tradisi Malam Kamis Majelis Shalawat Diba' Bil-Mustofa”, Ar-Raniry: Internatonal Journal of Islamic Studies 2, no. 1 (2014).

${ }^{18}$ Siti Qurrotul Aini, "Tradisi Qunut dalam Shalat Maghrib di Pondok Pesantren Wahid Hasyim Yogyakarta: Studi Living Hadis”, Jurnal Living Hadis 1, no. 2 (2016), 230-231.

${ }^{19}$ The full text of the hadith is:

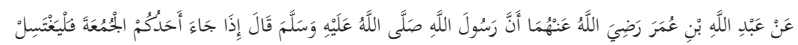

${ }^{20}$ J.W.M. Bakker Sj., Filsafat Kebudayaan (Yogyakarta: Kanisius, 1990), 121.

${ }^{21}$ Bakker Sj.

${ }^{22}$ Robert H. Laurer, Perspective on Social Change, transl. Alimandan (Jakarta: Rineka Cipta, 2003), 404-405. 
situation; (e) the degree of social and political inequality between both groups; (f) the selection and the integration may contain of certain cultural elements. Cultural acculturation often leads to conflict (between two or more social groups involved), and the potentials which leads to conflict. ${ }^{23}$ Even so, there are at least five positive values that can be obtained from social conflicts, namely: (a) building and strengthening boundaries of awareness and group mobility; (b) reducing hostility and destruction; (c) being a balance mechanism of close social relations; (d) forming social relations (antagonistic cooperation); (e) stimulating motivation (call for allies). ${ }^{24}$

One example of coercion in acculturation is Dutch and Portuguese colonialism in Indonesia. The colonialists forced new rules or ideas into their colonies, such as the coercion to convert to Christianity, to use the colonialists' language, and tradition. ${ }^{25}$ In contrast, the acculturation model of Hindu and Islamic culture into Javanese culture was more voluntary. ${ }^{26}$ It shows that the acculturation between religion and local culture can be verified by its historicity in Indonesians' tradition.

As the most important element, culture involves human creativity, intention, and taste, which is all human power and activities to cultivate and change nature. Culture consists of three components, namely a system of ideas and concepts (eidios), a series of human's patterned actions and activities (ethos), and material culture. ${ }^{27}$ Culture in society is always developing and changing; change is a normal and inherent reality in culture. Many factors cause cultural changes, including invention, discovery, innovation and cultural contact (contact with another culture). In a culture, change is a symbolic, continuous, cumulative, and progressive process. ${ }^{28}$

\section{${ }^{23}$ Laurer.}

${ }^{24}$ M. Atho Mudzhar, Pendekatan Studi Islam dalam Teori dan Praktek (Yogyakarta: Pustaka Pelajar, 1998), 238.

${ }^{25}$ Sidi Gazalba, Pengantar Kebudayaan Sebagai Ilmu (Jakarta: Pustaka Pelajar, 1967), 122.

${ }^{26}$ Gazalba.

${ }^{27}$ Kroeber, Anthropology (New York: Harcout, Brace, and Company, 1948), 292.

${ }^{28}$ Robert H. Laurer, Perspective of Social Change, transl. Alimandan (Jakarta: Rineka Cipta, 2003), 392. 
Culture is not a static thing, but its values continue to develop in accordance with time. The development process of culture can accept new elements from outside as long as they are appropriate and required by culture itself. ${ }^{29}$ In this study, Islam as a religion acculturating with local culture in Puncu Sub-District, Kediri, also shows significant changes.

Several factors are needed to encourage acculturation between culture (acculturation agents), which include:

a. Customary leaders; is a person who is entrusted by a member of his tribe to be the leader of a social group as mediators or problem solvers;

b. Religious Leaders; is a person who has a deep religious knowledge and gives his role and function in the development of culture, religious preaching, scientific transmission, religious education, social change, religious institutions, patterns of religious thought, and the community's political attitudes; ${ }^{30}$

c. Government and government officials that are politically and administratively authorized to provide support and services in order to bring order, peace and prosperity for the society. Government in the context of this study was village-level government officials throughout Puncu sub-district Officials.

\section{Puncu Muslim Community's Living Sunna}

Puncu is derived from Javanese, Puthuk/Muncu (hills) and is used to name a hamlet, a village, and a district in Kediri, District, East Java Province. ${ }^{31}$ Puncu Sub-District has an area of 52,732 square meters and is located in a cool climate mountainous area.

${ }^{29}$ Imam Barnadib, Pendidikan Perbandingan (Yogyakarta: Andi Offset, 1988), 38.

${ }^{30}$ Martin van Bruinessen, Kitab Kuning, Pesantren, dan Tarekat (Bandung: Mizan, 1995), 253.

${ }^{31}$ Focus Group Discussion with Puncu villagers, Puncu, Kediri, July 23, 2017 at Darussalam Mosque, Sidomulyo, Puncu. 
Puncu community main livelihoods are farming, especially chili, vegetables, sugar cane, papaya, and corn. ${ }^{32}$

Puncu Sub-District is home to 59,548 inhabitants, with the highest population density in Gadungan Village (15,833 inhabitants) and the lowest one in Watugede Village (2,789 inhabitants) ${ }^{33}$ Most inhabitants embraced Islam (42,839 inhabitants), and some embraced Protestantism (914 inhabitants), Roman Catholicism (1,450 inhabitants), Hindu (120 inhabitants), and Buddhism (7 inhabitants), and Javanese Kejawen (33 inhabitants). ${ }^{34}$

Every community experiences a process of discovery and formation of values which they recognized and accepted as life guidance and controllers. The community shapes its life tradition using these values. ${ }^{35}$ Such values are also owned by Puncu inhabitants who experience important life processes starting from birth, marriage, and then death. These values gradually become religious rite and tradition. The living Sunna traditions are formed:

\section{a. Living Sunna at Birth}

In the birth cycle, there are at least three phases that must be taken by Puncu Muslim community, namely pregnancy (pre-birth), birth, and post-birth phases. The first ceremony conducted was telonan (three; Javanese), which is conducted when a fetus is three month old. The Puncu community believes that the telonan ceremony is very meaningful ceremony because it is intended to ask Allah the almighty to keep the fetus and the mother healthy. In addition, it is believed that human spirit (ruh) because at the age of entering three months, the spirit is

\footnotetext{
${ }^{32}$ Field observations, July-August 2017.

${ }^{33}$ Observation in Puncu Sub-District Office, Kediri, July 6, 2017.

${ }^{34}$ The data were collected from all but three (Sidomulyo, Watugede, and Wonorejo) villages in Puncu Sub-District, during field observations July-August 2017.

${ }^{35}$ Hidayat, Akulturasi Islam dengan Budaya Melayu: Studi Tentang Ritus Siklus Kehidupan Orang Melayu di Pelelawan Propinsi Riau (Yogyakarta: Perpustakaan Pascasarjana, 2007), 200.
} 
inserted into the fetus. ${ }^{36}$ The tradition is an embodiment of the prophet's hadith about inserting the spirit to the fetus. ${ }^{37}$

"Telonan" ceremony contains various kinds of charity and praying activities. The food prepared include nasi tumpeng (rice cone), jenang abang (red porridge served with brown sugar and coconut milk), punar rice on takir plonthang, etc. ${ }^{38}$ Readings include al-'Ashr, al-Qadr, and al-Insyirah chapters from the Qur'an. Each chapter is read seven times, and usually ends with prayers. ${ }^{39}$ The next ceremony is tingkeban or pitonan (seven; Javanese); it is when the fetus is seven month old Puncu Muslim. The ceremony is similar with telonan ceremony and is intended to ask for protection and help so that the pregnancy runs smoothly. ${ }^{40}$ Pitonan ceremony is a living Sunna based on the hadith of Sahih Ibn Hibban. ${ }^{41}$

When a baby is born, Puncu community carries out "brokohan" ceremony. Brokohan is said to be derived from Arabic, "barakah" (blessing), in hope that the baby born will be blessed. Brokohan is carried out by inviting close neighbors and burial of the placenta. In this ceremony prayers are read which aim to make the child born healthy, as well as the family, especially his parents. Brokohan consists of offerings containing

\footnotetext{
${ }^{36}$ Focus Group Discussion Wonorejo villagers, Puncu, Kediri, August 14, 2017, at alAbror mosque, Biro, Wonorejo.

${ }^{37}$ The full text of the hadith is:

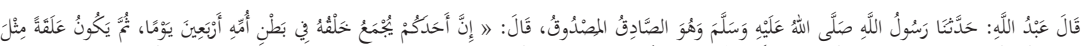

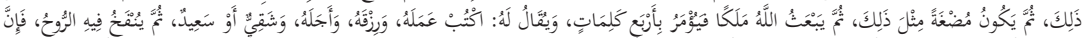

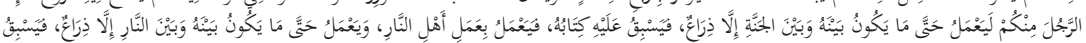

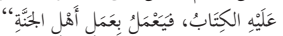

See al-Bukhari, Shahih al-Bukhari, "Bab Zikr al-Malaikah".

${ }^{38}$ Focus Group Discussion with Watugede villagers, Puncu, Kediri, July 30, 2017, at al-Huda mosque.

${ }^{39}$ Focus Group Discussion with Gadungan villagers, Puncu Kediri, July 22, 2017, at Darussalam mosque, Gadungan. $14,2017$.

${ }^{40}$ Focus Group Discussion with Wonorejo villagers, Wonorejo, Puncu, Kediri, August

${ }^{41}$ The full text of the hadith is:

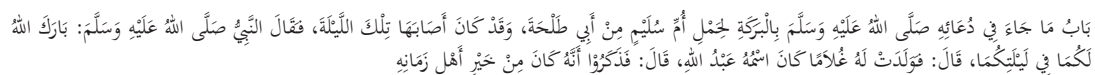

See Ibn Hibban, Shahih Ibn Hibban, "Bab Zikr Kunyah Hadha as-Saby”. 
cone, ingkung (chicken), gudhangan, red and white porridge, and also other traditional snacks. ${ }^{42}$ In general, the series of Qur'an verses read in the ceremony of a baby's birth include: Ayat Kursi 7 times, Chapter al-Insyirah 3 times, Chapter alQadr 7 times, Chapter al-Ikhlas 7 times, Chapter al-Falaq once, Chapter an-Nas once, and Chapter al-Fatihah once, and prayers.

The next ceremony is sepasaran bayi ceremony (one week) which is carried out after baby's birth. According to Javanese calculations, sepasaran ceremony is performed when the baby is five days old (sepasar) along with the separation of baby's umbilical cord (puputan). ${ }^{43}$ Usually more guests visit to see the baby (jagong bayen) at sepasaran night compared to other days. ${ }^{44}$ Some Muslim inhabitants prefer to call it "aqiqahan" or "walimah tasmiyah", which refers to the process of naming the baby in the fifth day after birth. Usually the guests read parts of the Qur'an, including al-Insyirah (7 times), al-Qadr (7 times), al-Ikhlas (3 times), mu'awwidzatain (1 time), and al-Fatihah chapters (1 time), as well as listening to sermon (mau'izhah hasanah), Salawat Dhiba, and prayers.

The recitation of Salawat Dhiba (srokal) is carried out during aqiqahan ceremony. The baby is shown to the guests; guests may kiss the baby's forehead, rub his/her head, or lightly blow on the baby's head. The ceremony usually also includes cutting a few strands of the baby's hair together with prayers led by religious leaders or elders and applying perfumes to infants and invitees. ${ }^{45}$ The sepasaran traditions carried out by Puncu Muslim community constituted the living Sunna based on the hadith. ${ }^{46}$

${ }^{42}$ Focus Group Discussion with Puncu villagers, Puncu, Kediri, July 23, 2017, at Nurussalam mosque, Margomulyo, Puncu.

${ }^{43}$ Focus Group Discussion with Manggis villagers, Puncu, Kediri, August 3, 2017, at Linggar Jati mosque.

${ }^{44}$ Focus Group Discussion with Manggis villagers, Puncu, Kediri, August 3, 2017, at Linggar Jati mosque.

${ }^{45}$ Focus Group Discussion with Puncu villagers, Puncu, Kediri, on Sunday, 23 July, 2017, at Nurussalam mosque, Sidomulyo, Puncu.

${ }^{46}$ Examples of hadith include: 
Another longstanding tradition found in Puncu Muslim community is a custom of slaughtering goats for sepasaran ceremony. People who cannot afford buying a goat may provide chicken meat. This tradition is the living Sunna of the hadith. ${ }^{47}$ The following ceremony is selapanan, telung lapahan, pitung lapan, and annual ceremonies which have similiar ritual and practice. ${ }^{48}$

\section{b. Living Sunna in the Customary Marriage}

Puncu Muslim community view marriage as a tie that contains social values and important values in their lives. They assess that men can get married when they have enough qualification, especially in form of job, and women when they are capable of taking care of the household properly. ${ }^{49}$ There are at least four objectives for their marriage, namely: (1) legalizing husband-wife relationship; (2) implementing Islamic teachings due to marriage as worshipping and one of Islamic sharia law; (3) clarifying social status; (4) maintaining regeneration. ${ }^{50}$ Puncu Muslim community carry out the marriage procession through the following stages:

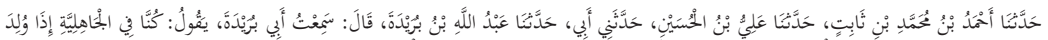

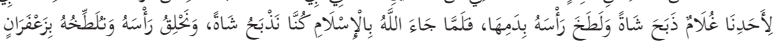

Aisyah mentioned in another hadith:

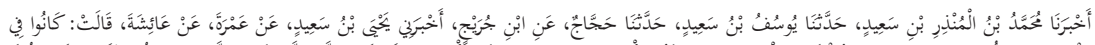

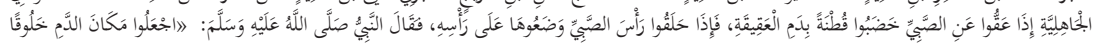

See Abu Dawud, Sunan Abu Dawud, "Bab fi al-"Aqiqah".

${ }^{47}$ The hadith says:

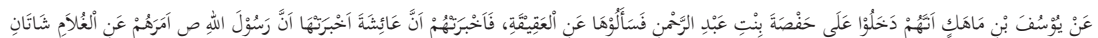

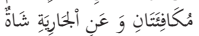

See Ibn Hibban, Shahih Ibn Hibban, "Bab Zikr al-Amr li Man 'Aqqa 'an Waladih an Yukhalliq Ra'sah fi Dzalik al-Yaum ba'd al-Halq".

${ }^{48}$ Focus Group Discussion with Asmorobangun villagers, Puncu, Kediri, August 12, 2017, at Miftahul Huda mosque.

${ }^{49}$ Focus Group Discussion with Satak villagers, Puncu, Kediri, August 5, 2017, at alHusna mushalla.

${ }^{50}$ Focus Group Discussion with Watugede villagers, Puncu, Kediri, July 30, 2017, at al-Huda mosque. 


\section{1) Nontoni, Nakokno, and Mbalesi}

Nontoni (watching) is a process of proposing to a woman. The process is usually not performed by the bridegroom himself, but through an intermediary called "dandan". If both parties agree, they go on with the next process, which is "nakokno" (asking), which is carried out by dandan from the bride side. Finally, the bride side informing the bride's family' approval or disapproval through a process called "mbalesi" (replying). Nontoni, nakokno, ${ }^{51}$ and mbalesi traditions are living Sunna advised by the prophet and is known as khitbah (asking in marriage). ${ }^{52}$

\section{2) Lamaran, Peningsetan, and Srahsahan}

In general, lamaran (engagement) and peningsetan are held simultaneously. The bridegroom candidate and his family come to the prospective bride's house and bring peningset (binder) in the form of: clothing, jewelry, and foodstuff. Peningsetan is a symbolic ceremony to show that both parties have agreed to establish a family bond, marked by the bridegroom candidate presenting a ring to the bride candidate..$^{53}$ The bride family's answer is usually not delivered directly, but in another occasion when the bride and her family visits the bridegroom candidate's family (srahsrahan). These traditions substantially adhere the marriage process suggested by the prophet. $^{54}$

\footnotetext{
${ }^{51}$ Such as the following hadith:

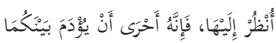

See Ahmad, Musnad Ahmad, "Bab Hadits al-Mughirah ibn Syu'bah".

${ }^{52}$ The hadith is:

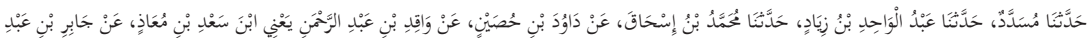

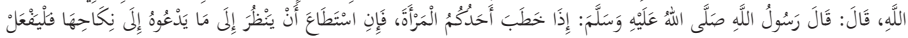

See Abu Dawud, Sunan Abu Dawud, “Bab fi ar-Rajul Yanzhur ila al-Mar’ah wa Huwa Yurid.

${ }^{53}$ Focus Group Discussion with Manggis villagers, Puncu, Kediri, July 29, 2017, at Linggar Jati mosque.

${ }^{54}$ The hadith is:

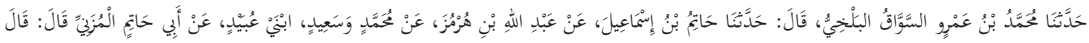




\section{c. Marriage Process}

In the marriage process, there are several stages where traditions and religiousteachings intersect. Firstis rapak (Arabic, rafa' $a$, meaning to raise or foster), which is a teaching process towards the prospective couples before entring a real marriage contract. In addition, rapak is intended as an administrative process of marriage registration and determining that both bride and groom are ready to marry. ${ }^{55}$ Second is manggulan, a form of tirakatan (a focused period of spiritual practice or cultivation) prior to marriage by not organizing festivities or big programs involving gamelan sounds or attractions. ${ }^{56}$ Uniquely, Puncu Muslim community changed the manggulan concept with organizing prayer program with neighbors, elders, community leaders, and religious leaders. Third, religious marriage ceremony, including the implementation of ijab kabul (Islamic marriage contract) performed in a Religious Affairs Office (Kantor Urusan Agama, KUA) or in the bride's home, as a legal requirement of marriage and the state's registration and official recognition. ${ }^{57}$ Fourth is wedding reception, which is a form of gratitude for the smooth marriage ceremony a symbolic announcement of the marriage. The reception consists of two events, namely time pengantin (bride and groom's meeting) and bece'an reception. ${ }^{58}$

Temu pengantin (bride and groom's meeting) is held after the religious wedding ceremony. The bride and the groom are brought together while being accompanied by the bridesmaids. During the process, attendeed read salawat

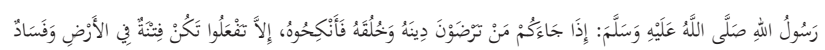

See at-Tirmidziy, Sunan at-Tirmidziy, "Bab Ma Ja'a min Man Tardlaun 'an Dinih".

${ }^{55}$ Focus Group Discussion with Watugede villagers, Puncu, Kediri, July 30, 2017 at al-Huda mosque.

${ }^{56}$ Focus Group Discussion with Gadungan villagers, Puncu, Kediri, July 22, 2017.

${ }^{57}$ Focus group discussion with Watugede villagers, Puncu, Kediri, on Sunday, 30 July 2017 at al-Huda mosque.

${ }^{58}$ Focus group discussion with Manggis villagers, Puncu, Kediri, on Saturday, 29 July 2017, at Linggar Jati mosque.
} 
(srokal) or often followed by traditional customaries such as liron, gantal, ngidak endok, drinking water, and so on. ${ }^{59}$ Bece'an (donation) is a custom of contributing something (usually rice, sugar, or money) to a member of society who hosts a program such as marriage. ${ }^{60}$

The wedding reception traditions carried out by Puncu Muslim community is a living Sunna from the prophet's hadith in Shahih al-Bukhari. ${ }^{61}$ Likewise, the society's attitude and attention to attend a wedding reception is also a form of living Sunna supported by the hadith. ${ }^{62}$

\section{Living Sunna in Funerals}

Physically, death is a natural process when human's brain system, nervous systems, and organs stop working. When a member of community passes away, Puncu Muslims usually recite istirja' while closing the deceased's eyes, folding and crossing the deceased's arms, covering the deceased with a long cloth, then laying the deceased on a couch or a long table to be bathed. Such process constitutes the living Sunna based on the hadith of the Holy Prophet. ${ }^{63}$

\footnotetext{
${ }^{59}$ Focus group discussion with Satak villagers, Puncu, Kediri, on Saturday, 5 August 2017 al-Husna musalla.

${ }^{60}$ Focus group discussion with Gadungan villagers, Puncu, Kediri, on Saturday, 22 July 2017, at Darussalam mosque, Gadungan.

${ }^{61}$ The text is:

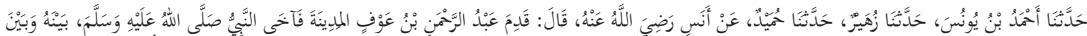

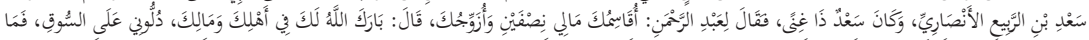

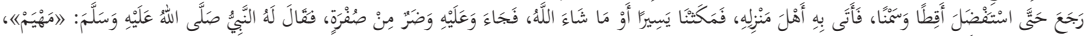

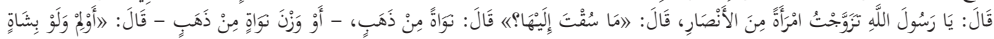

See Al-Bukhariy, Șaḥịh al-Bukhārī; Bab Kitāb al-Nikāḥ, Bab Mã Jā'a fi Qaulihi Ta'āla. ${ }^{62}$ The hadith is:

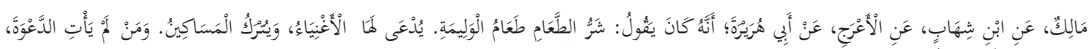

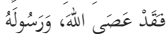

See Malik, al-Muwatha', "Bab Kitāb an-Nikāḥ, Mā Jā’a fi an-Nikāḥ”.

${ }^{63}$ The hadith is:

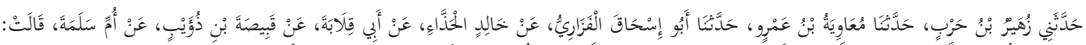

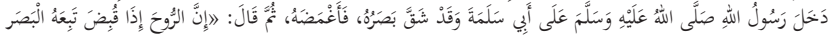

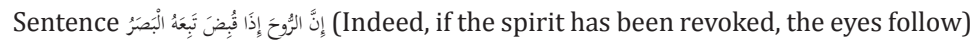


Furthermore, the obituary was announced to the community members through mosques and musallas' audio speakers, and kentongan or "dodolilit" (wood-made percussion instrument). ${ }^{64}$ The deceased is then taken care according to Islamic law, starting with purifying and bathing the deceased, putting on burial shroud, praying for the deceased, and then burying the deceased. ${ }^{65}$ These processes of taking care the deceased, as well as hastening the process $^{66}$ and reading talqin ${ }^{67}$ prayer are in accordance with the prophet's advice in his hadith. ${ }^{68}$

The deceased's family then organize a traditional "bungkeng ungkur-ungkur" ritual (Javanese: two piles of rice facing different direction). The attendees recite tahlil readings and praying together for the deceased's spirit. ${ }^{69}$ The ritual is continued in the following

is understood as a command to close a dead person's eyes right immediately after he/she died. See Muslim, Șaḥịh Muslim, "Kitab al-Janā’iz, Bab fi Ighmadh al-Mayyit wa ad-Du’ā lahu Idza Hadlara".

${ }^{64}$ Interview with Puncu villagers, Puncu, Kediri, July 23, 2017, at Nurussalam mosque, Sidomulyo, Puncu.

${ }^{65}$ Interview with Asmorobangun villagers, Puncu, Kediri, August 12, 2017, at Miftahul Huda mosque.

${ }^{66}$ The hadith says:

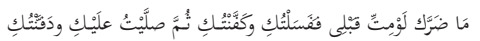

See Ahmad ibn Hanbal, Musnad Ạ̣mad ibn Ḥanbāl, "Musnad as-Ṣadīqah 'Aisyah".

${ }^{67}$ The hadith says:

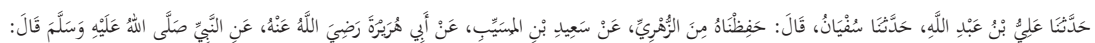

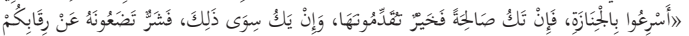

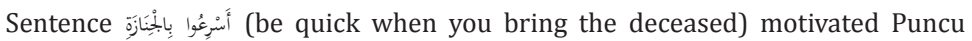
inhabitants to manage the dead person immediately together. See al-Bukhari, Sahịh alBukhārī, "Kitāb al-Janā'iz, Bab as-Sur'ah bi al-Janāzah".

${ }^{68}$ The hadith says:

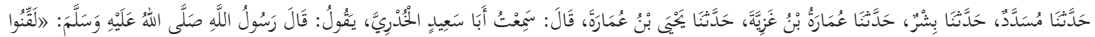

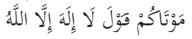

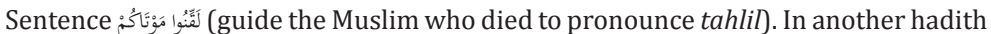
the prophet said that after burrying a dead Muslim, one should pray for the deceased and ask for forgiveness so that the deceased stays in faith and can answer the two angels's questions. The prophet says:

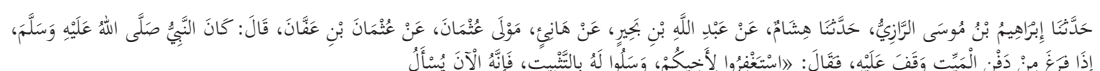

See Abu Dawud, Sunan Abi Dawud, "Kitab al-Janā’iz, Bab fi Talqīn".

${ }^{69}$ Interview with Asmorobangun villagers, Puncu, Kediri, August 12, 2017, at Miftahul Huda mosque. 
day, but it is called pidak'an (redeemer; Arabic الفداء) or zikr fida'. Broadly speaking, zikr fida' is divided into two types, namely: zikr fida' shugra by reading tahlil 70,000 times, and zikr fida' kubra by reading chapter al-Ikhlas 100,000 times. $^{70}$ This tradition is a living Sunna as advised by the prophet in a hadith. ${ }^{71}$

The following ceremony is named based on funeral ceremonies the death day. Therefore, it is named as telung dinanan (the third day after death), ${ }^{72}$ pitung dinanan (the seventh days after death), patang puluhan (the fortieth day of death), satusan (the hundredth day of death), pendak sepisan or setaunan (one year after death), pendak kapindho or rongtaunan (two years after death) ${ }^{73}$, and sewonan (one thousand days after death). The last ceremony (sewonan) is usually organized with a larger concept than previous events because it is considered as the peak of the slametan when someone dies.

One similarity found in most rituals/ceremony carried out by Puncu Muslim community is ujub tradition. Ujub is a prayers addresed to Allah using Kejawen values. ${ }^{74}$ For example:

"Nyuwun sewu dumateng bapak sedoyo, ingkang sampun
lenggah wonten dalemipun Bapak..... Niki, kulo ingkang
ngijabaken ingkang gadah hajat niki.... Monggo dipun rincangi
dedungo maring Allah kapindu Rasulullah nyuwun teguh
tegen anggenipun momong anak putunipun, nyuwun rahayu
wilujeng selamet gangsar anggenipun pados sandang kalian
tedo, sing sabab kawuningane Gusti, Bopo Adam, Ibu Hawa, ibu
bumi, bopo kuwoso, ibu sasi bopo suryo, ibu bengi bopo raino

\footnotetext{
${ }^{70}$ Interview with Asmorobangun villagers, Puncu, Kediri, August 12, 2017, at Miftahul Huda mosque.

${ }^{71}$ The hadith says:

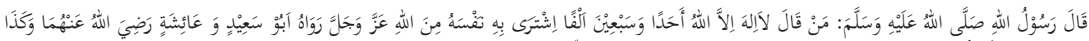

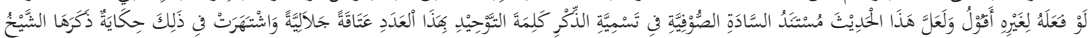

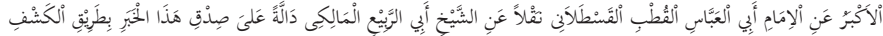

${ }^{72}$ Interview with Puncu villagers, Puncu, Kediri, July 23, 2017, at Nurussalam mosque, Margomulyo, Puncu.

${ }^{73}$ Interview with Wonorejo villagers, Puncu, Kediri, August 14, 2017, at al-Abror mosque, Biro.

${ }^{74}$ Interview with Sidomulyo villagers, Puncu, Kediri, August 13, 2017, at Darussalam mosque, Sidomulyo.
} 
ingkang dipun suwuni sandang kalian tedo, pramilo dipun suwun semangatipun ingkang wilujeng."

Prayers in $u j u b$ is a living Sunna, that is a command to pray to Allah swt. It is supported by a hadith which encouraged Muslims to pray consistently. ${ }^{75}$ The ujub tradition is a living Sunna that is widely practiced. Puncu Muslim community, especially the uneducated one practice the rituals even though they never knew the sharia basis of the prayer, they get used to recite it.

\section{The Acculturation Process of Puncu Muslim Community}

The author used several components to parse the acculturation process in Puncu Muslim community, including agents, channels, elements, layers, and the community's reactions to other cultures.

\section{a. Acculturation Agents}

There are two main groups of factors to consider, namely the ulama (Islamic scholars) and the government. Puncu Muslim community has always been very obedient to the religious ceremonial traditions, such as birth, marriage, and death funeral ceremonies. These traditions are influenced by religious leaders or clerics (kyai) in Puncu. Kyai has big influence on Puncu Muslim community because they acted as spiritual and social leaders. ${ }^{76}$ Puncu Muslim community

\footnotetext{
${ }^{75}$ The hadith says:

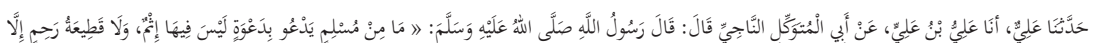

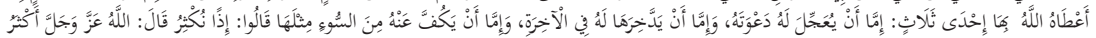
1990), 472.

See 'Ali ibn al-Ja'diy al-Baghdadiy, Musnad Ibn al-Ja'diy (Beirut: Muassasah Nadir,
}

Also the following hadith:

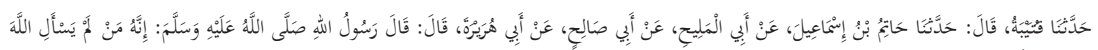

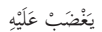

See at-Tirmidziy, Sunan at-Tirmidziy, “Abwāb ad-Da'āwat, Bab Mā Jā’a fī Fadl adDu'ā".

${ }^{76}$ According to Zamahsyari Dhofier, the term "kyai" in Javanese is used for three 
regards kyai as a highly respected figure. The presence of kyai in a religious ceremony is a symbol of spiritual legality, indicating that the ceremony is a religiously valid ceremony. Kyai introduced Islam to the community with tolerance, so the Puncu community could accept the Islamization process well. Minimizing the potentials of conflict, tension, and friction is the preferred goal for the creation of harmony in the society.

The Puncu village and sub-district governance also has a big role in the acculturation process. When the village and sub-district heads and their instruments make a policy, they always coordinate with religious leaders. About $95 \%$ of village government officials in Puncu Sub-District are Muslim. The big number of Muslim government officials is vital in the dissemination of Islamic teaching and its acculturation with the local culture. In addition, the form of government's assistance to Islamic educational institutions and the construction of worship places is a form of government's attention to the development of Islam in Puncu. The harmonious relationship between the government and religious leaders is the main factor sustaining the tradition in the community. The government wants its society people to live peacefully and calmly. Similarly, the Muslims community hopes they can freely carry out their religious activities in peace.

\section{b. Acculturation Channels}

Acculturation channels in this context are institutionalized social spaces which become a meeting place between civilized people and culture. There are three identified channels. First, Islamic organization such as Nahdlatul Ulama (NU). NU contributes to the acculturation

different types of titles, namely: (1) as an honorary title for items considered to be sacred, such as: "Kyai Garuda Kencana" (name of a golden horse cart in Yogyakarta palace; (2) honorific title for old person in general; (3) title given by the community members to an Islamic expert who owns or runs a pesantren (Islamic Boarding House) and teach classical Islamic books. See Zamakhsyari Dhofier, Tradisi Pesantren: Studi Tentang Pandangan Hidup Kyai (Jakarta: LP3ES, 1982), 55. 
process between Islam and local culture in Puncu Muslim community. The influence of $\mathrm{NU}$ ideas and movement is observable in the community's practice of worship. NU is easily accepted by Puncu Muslim community due to its moderate religious understanding so it is easier to integrate with Puncu community's traditions. In addition, most Islamic religious leaders in Puncu are alumni of pesantren (Islamic boarding school) affiliated with $\mathrm{NU}$ around the sub-district (mostly from Pare and Kepung Sub-Districts).

Second, places of worship, especially mosques and musallas in Puncu Sub-District, play an important role as a place of interaction between Puncu Muslim community to participate in various religious activities in their neighborhood, such as tahlil, Yasin reading, birth, marriage contract, and funeral ceremonies. This shows that the process of religious acculturation with the local culture runs effectively. This dialectic fosters harmony in building new community traditions, namely living Sunna as a form of religious acculturation with local culture.

Third, educational institutions, especially madrasah and boarding schools (pesantren) in Puncu and its surroundings have an important influence in the process of acculturation between religion and local culture. There are at least six Islamic boarding schools in Puncu Sub-District, namely: al-Miftah Islamic Boarding School Biro Wonorejo Puncu, Bustanul Ulum Islamic Boarding School Tanggung Mulyo Puncu, Al-Badar Hufadz Islamic Boarding School Templek Gadungan Puncu, Darul Manar Islamic Boarding School Jl. Kepung No. 99 Puncu, Miftahul Ulum Islamic Boarding School Jl. Subur Puncu, and Roudlotul Muta'allimin Islamic Boarding School Jl. Subur, Puncu, Kediri. These pesantrens provide students (santri) with the religious knowledge needed by the community in their daily lives. For example, they are equipped with how to care for bodies, giving birth, marriage, and funeral ceremonies. Of course, the material they receive is in accordance with the 
needs of the community. This is where the important role of pesantren can be seen in the process of maintaining living Sunna in society.

\section{c. Elements of Acculturation}

Among elements of acculturation is the influence of faith and tradition in shaping the process of acculturation that manifests in the living Sunna. The issue of faith is crucial because animism and Hinduism were dominant in Puncu area before the arrival of Islam. For example, pre-Islamic Puncu inhabitants believed that nature is superior to human reason and mind, so these people believed in spells, symbols, and myths. Example include decorating wedding spot using young coconut leaf, cooking yellow rice in birth and funeral ceremonies, and using Hindu symbols (especially in Manggis village). Puncu Muslims view these to a tradition and not a religious teaching. The acculturation between religion and local culture can shift the inhabitants' old beliefs to Islam as monotheistic religion.

Tradition is another element which plays important role because this habit is carried out repeatedly in the same form and is passed down from one generation to the next. Traditional community in Puncu Sub-Districtstill holds many local traditions related to myths which they believed. However, the ulama and kyai accommodate the acculturation between religion and local culture. They are tolerant in spreading Islamic teachings by allowing local traditions to proceed and they gradually insert Islamic values into the local tradition. The ulama's approach provides many benefits, including maintaining the positive traditional values, avoiding cultural shocks, and increasing the community's acceptance of Islamic teachings.

\section{d. Recipient Communities}

Before Islam spreaded and dominated in Puncu, Puncu community had first embraced Hinduism and local 
beliefs. However, the community's (acceptors) attitude is not uniformed. There are five attitudes emerged. First, members of community who want to accept the acculturation of Islam with local culture; they are represented by inhabitants who have formal or informal education. Second, the "early adopter" group; they are highly respected leaders of community, mostly are religious leaders and local leaders. Third, the "early majority" group; they are community leaders who politically want to win public support and avoid horizontal conflict. Fourth, the "late majority" groups; they are the majority of inhabitants who accept Islamic teachings lately and are dominated by inhabitants with low education, such as farmers and manual laborers. Fifth, the conservative and traditional groups such as shamans and Kejawen figures who have a strong influence in society, especially towards the late majority class.

\section{e. Reactions Emerging from the Acculturation}

Puncu inhabitants' reaction to the acculturation process between religion and local culture tends to be positive and accommodative. The acculturation process in general run well. However, negative reaction also emerged in limited scope because the local customs, traditions and polytheistic religions (animism and dynamism) must adhere to a new religion.

The negative reaction emerges from two identified groups, namely: (1) traditional leaders such as shamans and Kejawen adherents; (2) revivalist Muslim groups. The traditional leaders felt that their roles, for example in birth and funeral ceremonies, have diminished, especially in villages where religious leaders have a strong influence (e.g., in Gadungan, Wonorejo, and Sidomulyo villages). Moreover, their position is increasingly weakening with increasing public understanding of Islam. Second is the revivalist Muslim group in Puncu which prioritizes Islamic law rather than sufism, such as Indonesia Institute of Islamic Da'wah (Lembaga 
Dakwah Islam Indonesia, LDII) group. Although LDII is small in number, it has a fairly extensive network. They disagree with the Islamic da'wah approach adopted by kyai who are more inclined to the process of tolerance of local culture and consider the process like as bid'ah (innovation in religious matters in Islam) and haram (forbidden/sinful act).

\section{Conclusion}

Three main things can be concluded from the above discussion. First, the living Sunna practiced by Muslim communities in Puncu Sub-District (e.g. in birth, marriage, and funeral ceremonies) is a form of living Sunna that has become a tradition and custom. Although the majority of Puncu Muslim community do not understand the dalil (religious reasoning) of the traditions at birth, marriage, and funeral ceremonies, but they practice the traditions well. Second, the living Sunna is supported by the nearly perfect acculturation process between religion and local culture, so that the social conflicts emerging from the change in local traditions can be avoided. Third, some factors which cause the acculturation process include:

1. Islam in Puncu was spreaded using the local culture as a media. The local community's acceptance helps the acculturation process between Islam and the local culture runs smoothly and Puncu inhabitants felt comfortable with it;

2. The da'i (preachers) and kyai who became religious leaders in Puncu are moderate clerics. They spread Islam in piece while preserving the local traditions. They slowly convinced the community to abandon traditions which were against Islamic principles and to modify some other traditions. Consequently, more and more inhabitants carried out the prophet's Sunna in their daily lives;

3. The village and sub-district government authorities in Puncu which held administrative and political power in Puncu area protect religions and individual believers. Most village and sub-district government officials in Puncu are Muslims, 
but they treated all religions equally. The officials' service professionalism was a key factor in the natural acculturation process of religion and local culture;

4. Channels of acculturation between religion and local culture developed naturally. Islamic education centers such as Islamic boarding schools, mosques, musallas, and religious organizations such as $\mathrm{NU}$, strongly support the acculturation process. Living Sunna became a tradition in Puncu Muslim community because the acculturation channels operated well;

5. Religious and community leaders as well as village and sub-district governments in Puncu ensured that the acculturation elements such as aqidah (Islamic creed) and tradition can go hand in hand. The leaders and government officials minimized possible friction between religious leaders and traditional leaders.

Some from the study, it can therefore be assumed that the there is a need for further research on broader topics of the acculturation process between religion and local culture, not only limited to birth, marriage, and funeral ceremonies. The da'wah (Islamic preaching) model developed in Puncu should also be developed in other areas that have the same social characteristics, namely $d a^{\prime} w a h$ in peace and maintaining the traditions in the community. 


\section{REFERENCES}

\section{Book}

Amal, Taufik Adnan. Islam dan Tantangan Modernitas: Studi atas Pemikiran Hukum Fazlur Rahman. Bandung: Mizan, 1996.

al-Baghdadiy, Ali ibn al-Ja'diy. Musnad Ibn al-Ja'diy. Beirut: Muassasah Nadir, 1990.

Bakker Sj., J.W.M. Filsafat Kebudayaan. Yogyakarta: Kanisius, 1990.

Barnadib, Imam. Pendidikan Perbandingan. Yogyakarta: Andi Offset, 1988.

al-Bazar, Abu Bakr. Musnad al-Bazar, Volume 13. Madinah: Maktabah al-'Ulum wa al-Hikam, 1998.

Bruinessen, Martin van. Kitab Kuning, Pesantren, dan Tarekat. Bandung: Mizan, 1995.

al-Bukhariy. Shahih al-Bukhariy. n.d.: Dar at-Tuq an-Najah, n.d.

Dawud, Abu. Sunan Abu Dawud. Beirut: Maktabah al-'Asriyyah, n.d.

Dhofier, Zamakhsyari. Tradisi Pesantren: Studi Tentang Pandangan Hidup Kyai. Jakarta: LP3ES, 1982.

Hanbal, Ahmad ibn. Musnad Ahmad ibn Hanbal. n.p.: Muassasah arRisalah, n.d.

Hibban, Ibn. Shahih Ibn Hibban. Beirut: Muassasah ar-Risalah, 1988. . Sunan Ibn Majah, Volume 1. n.p.: Dar Ihya' al-Kutub al'Arabiyyah, n.d.

Hidayat. Akulturasi Islam dengan Budaya Melayu: Studi Tentang Ritus Siklus Kehidupan Orang Melayu di Pelelawan Propinsi Riau. Yogyakarta: Perpustakaan Pascasarjana, 2007.

Kaelan. Metode Penelitian Kualitatif Bidang Filsafat. Yogyakarta: Paradigma, 2005. 
Kartono, Kartini. Pengantar Metodologi Riset Sosial. Bandung: Mandar Maju, 1990.

Kroeber. Anthropology. New York: Harcout, Brace, and Company, 1948.

Ma'luf, Abu Luwis. Al-Munjid. Beirut: Dar al-Masyhur, 1984.

Mas'adi, Ghufron A. Pemikiran Fazlur Rahman Tentang Metodologi Pembaruan Hukum Islam. Jakarta: Raja Grafindo, 1997.

Moleong, Lexy J. Metodologi Penelitian Kualitatif. Bandung: Remaja Rosda Karya, 1991.

Mudzhar, M. Atho. Pendekatan Studi Islam dalam Teori dan Praktek. Yogyakarta: Pustaka Pelajar, 1998.

Muhadjir, Noeng. Methode Penelitian Kuantitatif. Yogyakarta: Rake Sarasin, 2002.

Muslim. Shahih Muslim, Volume 2. Beirut: Dar Ihya' at-Turath al'Arabiy, n.d.

Patton, Michael Qiunn. Qualitative Evaluation Methods. London: Sage Publication, 1987.

Rahman, Fazlur. Revival and Reform in Islam, transl. Aam Fahmia. Jakarta: Raja Grafindo Persada, 2001.

al-Shan'aniy, Abd al-Razaq ibn Hamam. Al-Mushannaf, Volume 3. Beirut: al-Maktab al-Islamiy, 1403.

Sukri, Sri Suhanjdati. Ijtihad Progrsif Yasadipura II. Yogyakarta: Gama Media, 2004.

Suryadilaga, M. Alfatih. Model-model Living Sunnah, Unpublished Paper.

at-Tirmidziy. Sunan at-Tirmidziy. Al-Mamlakah al-'Arabiyyah asSu'udiyyah: Dar an-Nasyr wa at-Tauzi', 2000. 


\section{Journal Article}

Aini, Adrika Fithrotul. "Living Hadis dalam Tradisi Malam Kamis Majelis Shalawat Diba' Bil-Mustofa", Ar-Raniry: International Journal of Islamic Studies 2, no. 1 (2014).

Aini, Siti Qurrotul. “Tradisi Qunut dalam Shalat Maghrib di Pondok Pesantren Wahid Hasyim Yogyakarta: Studi Living Hadis", Jurnal Living Hadis 1, no. 2 (2016).

Ali, Muhamad. "Kajian Naskah dan Kajian Living Qur'an dan Living Hadis", Journal of Qur'an and Hadith Studies 4, no. 2 (2015).

Aziz, Donny Khoirul. "Akulturasi Islam dan Budaya Jawa”, Fikrah 1, no. 2 (2013).

Farida, Umma. "Studi Pemikiran Fazlur Rahman Tentang Sunnah dan Hadis", ADDIN 7, no. 2 (2013).

Hayati, Naila. "Pemilihan Metode yang Tepat dalam Penelitian: Metode Kuantitatif dan Metode Kualitatif", Jurnal Tarbiyah al-Awlad 4, no. 1 (2015).

Qudsy, Saifuddin Zuhri. "Living Hadis: Genealogi, Teori, dan Aplikasi", Jurnal Living Hadis 1, no. 1 (2016).

Sumbulah, Ummi. "Islam Jawa dan Akulturasi Budaya: Karakteristik, Variasi, dan Ketaatan Ekspresif", el-Harakah 14, no. 1 (2012).

Umayah. "Living Hadits: Fenomena Bekam di Pesantren Eretan Indramayu", Holistik 15, no. 2 (2014).

\section{Focused Group Discussion}

Focused Group Discussion with Asmorobangun villagers, Puncu, Kediri, August 12, 2017, at Miftahul Huda mosque.

Focused Group Discussion with Gadungan villagers, Puncu Kediri, July 22, 2017, at Darussalam mosque, Gadungan.

Focused Group Discussion with Manggis villagers, Puncu, Kediri, August 3, 2017, at Linggar Jati mosque. 
Focused Group Discussion with Puncu villagers, Puncu, Kediri, July 23, 2017, at Nurussalam mosque, Margomulyo, Puncu.

Focused Group Discussion with Puncu villagers, Puncu, Kediri, July 23, 2017, at Nurussalam mosque, Sidomulyo, Puncu.

Focused Group Discussion with Satak villagers, Puncu, Kediri, August 5, 2017, at al-Husna musalla.

Focused Group Discussion with Watugede villagers, Puncu, Kediri, July 30, 2017, at al-Huda mosque.

Focused Group Discussion Wonorejo villagers, Puncu, Kediri, August 14, 2017, at al-Abror mosque, Biro, Wonorejo. 